\title{
Lead contamination induces neurodegeneration in prefrontal cortex of Wistar rats
}

\author{
Daniel Temidayo Adeniyi ${ }^{1}$, Peter Uwadiegwu Achukwu ${ }^{2}$ \\ ${ }^{\prime}$ Department of Medical Laboratory Science, School of Basic Medical Sciences, College of Pure and Applied Sciences, Kwara State University, Malete, \\ Kwara State, Nigeria \\ ${ }^{2}$ Department of Medical Laboratory Science, Faculty of Health Science and Technology, College of Medicine, University of Nigeria, Enugu Campus, \\ Enugu State, Nigeria
}

\begin{abstract}
Objectives: Neurodegenerative disorders have been associated with several environmental pollutants such as heavy metals. This study aimed at investigating the neurodegenerative impact of lead concentration obtained from the waterways in Kwara State, Nigeria on Wistar rats.

Methods: Twenty-first filial generation inbred adult male Wistar rats (Rattus norvegicus) with an average weight of 150-180 g were divided into two groups of ten animals. The highest mean concentration of lead obtained from the waterways of the three geographical zones of Kwara Nigeria was administered with water $\left(0.009 \mathrm{mg}\right.$ of $\mathrm{Pb}\left(\mathrm{CH}_{3} \mathrm{CO}_{2}\right) .3 \mathrm{H}_{2} \mathrm{O}$ per milliliter solution) to rats in the treatment group ad libitum for 65 days. The harvested prefrontal cortex was processed for paraffin embedding and the sections were stained for haematoxylin and eosin stain and Bielschowsky's silver impregnation stain, and glial fibrillary acidic protein (GFAP) and inducible nitric oxide synthase (iNOS) immunohistochemistry.

Results: The histochemical stainings revealed shreds of evidence of neuronal degeneration in the treatment group compared to the control group. Immunohistochemical analysis revealed marked astrocytosis, the hallmark of neuroinflammation, with induced oxidative stress in the treatment group compared to the control group.

Conclusion: These results indicate lead obtained from the three geographical zones of Kwara Nigeria may have a possible pathogenic role in development of neurodegenerative disorders and emphasize the effects of exposure to this environmental pollutant.
\end{abstract}

Keywords: environmental pollutants; lead; neurodegenerative disorders; neuroinflammation; oxidative stress

Anatomy 2018;12(3):128-134 @2018 Turkish Society of Anatomy and Clinical Anatomy (TSACA)

\section{Introduction}

Neurological impairments are fast becoming common global causes of disabilities. ${ }^{[1]}$ Maulik et al..$^{[2]}$ observed that prevalence of mental disabilities is higher in developing countries compared to those in developed countries. Environmental factors, such as environmental pollution, can influence the prevalence of these mental disabilities. ${ }^{[2]}$ Poor health quality and high contamination level of heavy metals in developing countries may also contribute to these prevalence rates. ${ }^{[3]}$ In recent times, the continual heavy metal contamination in waterways has been a global issue due to its persistence and resultant toxicity. ${ }^{[4,5]}$ Poor waste management and disposal, especially electronic waste (e-waste) disposal and recycling in developing countries were reported to enhance the elevated levels of heavy metal contamination in these regions. ${ }^{[3,-68]}$

E-waste is defined as used electronics intended for reuse, resale, salvage, recycling, or disposal. ${ }^{[9]}$ Osibanjo and Nnorom $^{[10]}$ reported that electronic waste devices are usually stored for a while for a perceived value - physical or emotional - before disposal with municipal waste in Nigeria. Because of the absence of a special framework for the separate collection and management of e-waste in Nigeria, these devices are disposed with Municipal Solid Waste (MSW) at open dumpsites and/or into waterways. ${ }^{[9-12]}$ Informal disassembling and recycling of e-waste in backyards was also reported in Nigeria where primitive 
methods were used in recovering materials from ewaste. ${ }^{[13-15]}$ The recovered materials are processed to reusable components and the unused portions are also stockpiled or dumped and landfilled. ${ }^{[1,16]}$ E-wastes contain more than a thousand different substances, of which many are toxic, heavy metals inclusive. ${ }^{[17,18]}$ These complex toxic substances, if not properly handled during recycling or disposal, adversely impact the environment. ${ }^{[1,19]}$ Corrosion of e-waste components after disposal result in mobility of incorporated heavy metals which travel with leachate to contaminate the environment. ${ }^{[20]}$ Leaching of these toxic heavy metals eventually contaminates the ground and surface water. ${ }^{[6]}$ The resultant effect is the high levels of heavy metals above the permissible limit recorded in Nigeria waterways. ${ }^{[5,21,22]}$

Lead is a soft, ductile, flexible and malleable metal with high thermal expansion and electrical conductivity. ${ }^{[23]}$ Being the 5 th most widely used metal, ${ }^{[2]}$ it is toxic and found in substantial amount in e-waste. ${ }^{[25]}$ Lead is commonly found in e-waste such as cathode ray tubes (CRTs) in computers monitors and televisions, fluorescent tubes, solder in printed circuit boards, as well as in liquid crystal displays (LCDs) and batteries. ${ }^{[1,26-29]}$ In Nigeria, the population is at risk of lead exposure because of the intense use of leaded gasoline, the poor recovery and recycling of automotive lead-acid batteries, and the uncontrolled ewaste disposal and recycling. ${ }^{[30,31]}$ Lead is not biodegradable. It stores faster in the human body than metabolized or excreted, and hence tends to bio-accumulate in concentrations above that found in the environment. ${ }^{[2]}$ It is a potent neurotoxin that disrupts the functional integrity of the neurons with resultant negative implication on memory and intelligence and cognitive deterioration..$^{[23,33-35]}$

This study aimed at investigating the neurodegenerative impact of lead concentration obtained from the waterways in Kwara State, Nigeria on Wistar rats as the experimental model.

\section{Materials and Methods}

This study was carried out in Kwara State, Nigeria in 2017. Experimental procedures used in this study were approved by the College of Medicine Research Ethics Committee, University of Nigeria, Enugu State (approval number: 025/02/2017) in line with the National Institute of Health (NIH) "Guide to the Care and Use of Animals in Research and Teaching".

The lead (II) acetate trihydrate $\left(\mathrm{Pb}\left(\mathrm{CH}_{3} \mathrm{CO}_{2}\right) .3 \mathrm{H}_{2} \mathrm{O}\right)$ salt used was obtained from the Department of Biochemistry, College of Pure and Applied Science, Kwara State University, Malete, Kwara State, Nigeria. $0.009 \mathrm{~g}$ of
$\mathrm{Pb}\left(\mathrm{CH}_{3} \mathrm{CO}_{2}\right) \cdot 3 \mathrm{H}_{2} \mathrm{O}$ was weighed and dissolved in 1 liter of double distilled demineralized water to form $0.009 \mathrm{mg}$ of $\mathrm{Pb}\left(\mathrm{CH}_{3} \mathrm{CO}_{2}\right) \cdot 3 \mathrm{H}_{2} \mathrm{O}$ per liter to form the final concentration of $0.009 \mathrm{mg}$ of $\mathrm{Pb}\left(\mathrm{CH}_{3} \mathrm{CO}_{2}\right) .3 \mathrm{H}_{2} \mathrm{O}$ per milliliter solution. This was based on the empirical measurement of heavy metals obtained in the waterways of the Kwara Nigeria in 2016 and reported by Adeniyi et al. ${ }^{[5]}$

Twenty (20) first filial (F1) generation inbred adult male Wistar rats (Rattus norvegicus) with an average weight of about 150-180 $\mathrm{g}$ were procured from the animal facility of Institute for Advance Medical Research and Training (IAMRAT), College of Medicine, University of Ibadan and employed in this study. Rats were allowed to acclimatize for 14 days and fed pelletized rat feed and water ad libitum throughout acclimatization before use. Plastic cages containing wood shaving bedding were used to house the rats. The bedding was changed once a day. They were kept in standard laboratory conditions under natural light-dark cycle at room temperature and maintained on standard laboratory rat pellets and given water ad libitum. These rats were divided at random into two groups of ten animals using the method of Daniel et al. ${ }^{[36]}$ The animals in the first group had access to diet and double distilled demineralized water ad libitum while those in the second group had access to diet and lead-contaminated water ad libitum. The duration of treatment lasted over a period of 65 days, a long-term standard for rats. ${ }^{[37]}$ The animals were sacrificed by cervical dislocation. The skulls of the sacrificed animals were opened using bone forceps to expose the brain. The skull was opened from the posterior part to leave the tissue intact. ${ }^{[38]}$ The prefrontal cortex was obtained from the anterior cerebral cortex. The harvested tissues were fixed in $10 \%$ buffered formol saline, grossed and processed for paraffin tissue embedding following Drury and Wellington ${ }^{[39]}$ technique. The processed sections were stained for histological, histochemical and immunohistochemical evaluation. Neuromorphological and histochemical analysis were carried out using haematoxylin and eosin $(\mathrm{H} \& \mathrm{E})$ staining technique ${ }^{[40]}$ and Bielschowsky's silver impregnation technique ${ }^{[41]}$ respectively. Immunohistochemical evaluation was carried out using glial fibrillary acidic protein $(\mathrm{GFAP})^{[2,43]}$ and inducible nitric oxide synthase (iNOS) $)^{[4+]}$ immunostaining techniques.

The stained sections were viewed and photographed with an Olympus U-D03 microscope (Olympus, Lake Success, NY, USA) captured with Olympus DP21. Photomicrographs of stained sections were obtained and reported. 


\section{Results}

There was no account of death recorded in the two groups throughout the 65 days of lead administration. The general neuronal morphology of the prefrontal cortex in adult male Wistar rats following administration with lead-contaminated water demonstrated by haematoxylin and eosin staining is shown in Figure 1. Sections from the prefrontal cortex of the control Wistar rats (Figure 1a) revealed intact and normal sized neurons with clear perikarya, centrally placed nucleus and small-sized neuroglia interspersed within normal neuropil stained slightly eosinophilic; whereas sections from the prefrontal cortex from the treatment group (Figure 1b) depicted numerous neurons with distorted morphology with different features of neurodegeneration, which includes red neuron, shrunken neurons with karyolitic nuclei, gliosis with focal neuropil vacuolation degeneration.

The neuronal membrane was demonstrated using Bielschowsky's silver impregnation stain (Figure 2). The section from the control group revealed normal neurons with well-outlined neuronal membrane and axons surrounding a clear cytoplasm (Figure 2a). The treatment group showed numerous neurons with various degenerative features characterized by pyknotic neurons with condensed chromatin, nuclear shrinkage; with some neuron having no nuclei and neuropil vacuolation (Figure $\mathbf{2 b}$ ).

Glial fibrillary acidic protein (GFAP) immunostaining was used to demonstrate reactive glial immunoreactivity (Figure 3). The treatment groups showed strong astrocyt- ic immunoreactivity (Figure 3b) compared with the control group (Figure 3a). Inducible nitric oxide synthase (iNOS) immunostaining (Figure 4) was used for the demonstration of oxidative stress. iNOS reactivity was intensely expressed in the treatment groups (Figure $4 b$ ) in comparison to the control group (Figure 4a).

\section{Discussion}

Several parameters were employed in this study to observe the morphology of the neurons in the prefrontal cortex of rats following lead contaminated water consumption. Based on the higher functions of cognitive abilities associated with prefrontal cortex of the brain, ${ }^{[4]}$ the morphology of the neurons located in this region was investigated to compare potential differences following lead exposure.

The results obtained with haematoxylin and eosin staining method (Figure 1) showed features of neurodegeneration in the treatment group (Figure 1b). The degeneration pattern of the neuron was apoptotic. These apoptotic neuronal cells are characterized by pyknotic nuclei involving irreversible condensation of chromatin in the nucleus and shrinkage of the cells. ${ }^{[46,47]}$ Changes observed in neurons from the treatment group suggested that neuronal cell death occurred in the apoptotic mode. The excessive neuronal cell shrinkage is the result of the tightly packed cells that are smaller in size compared with the control in accordance with the findings of Olajide et al $^{[48]}$ Stefanis et al ${ }^{[49]}$ described neuronal apoptotic cells with tightly packed with or without fragment which further supports our observation.
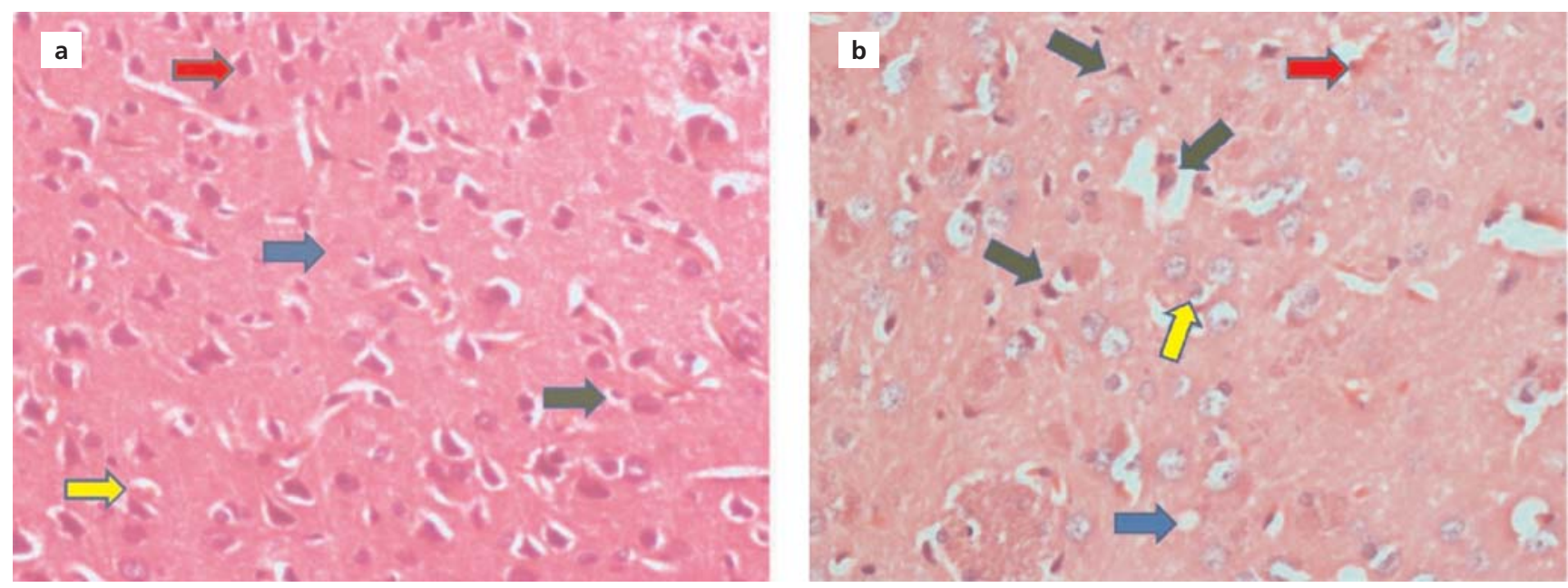

Figure 1. (a) Control group had intact neurons (red arrow), normal blood vessel (yellow arrow) in the neuropil area that stained slightly eosinophilic (blue arrow) and glial cells interspersed within this region (green arrow). (b) The cortical sections of rats from lead-contaminated group showed features of neurodegeneration including red-colored neurons (red arrow), shrunken neurons with karyolysis nuclei (green arrows), gliosis (yellow arrow) and focal neuropil vacuolation (blue arrow) (×400 magnification, haematoxylin and eosin stain). [Color figure can be viewed in the online issue, which is available at www.anatomy.org.tr] 

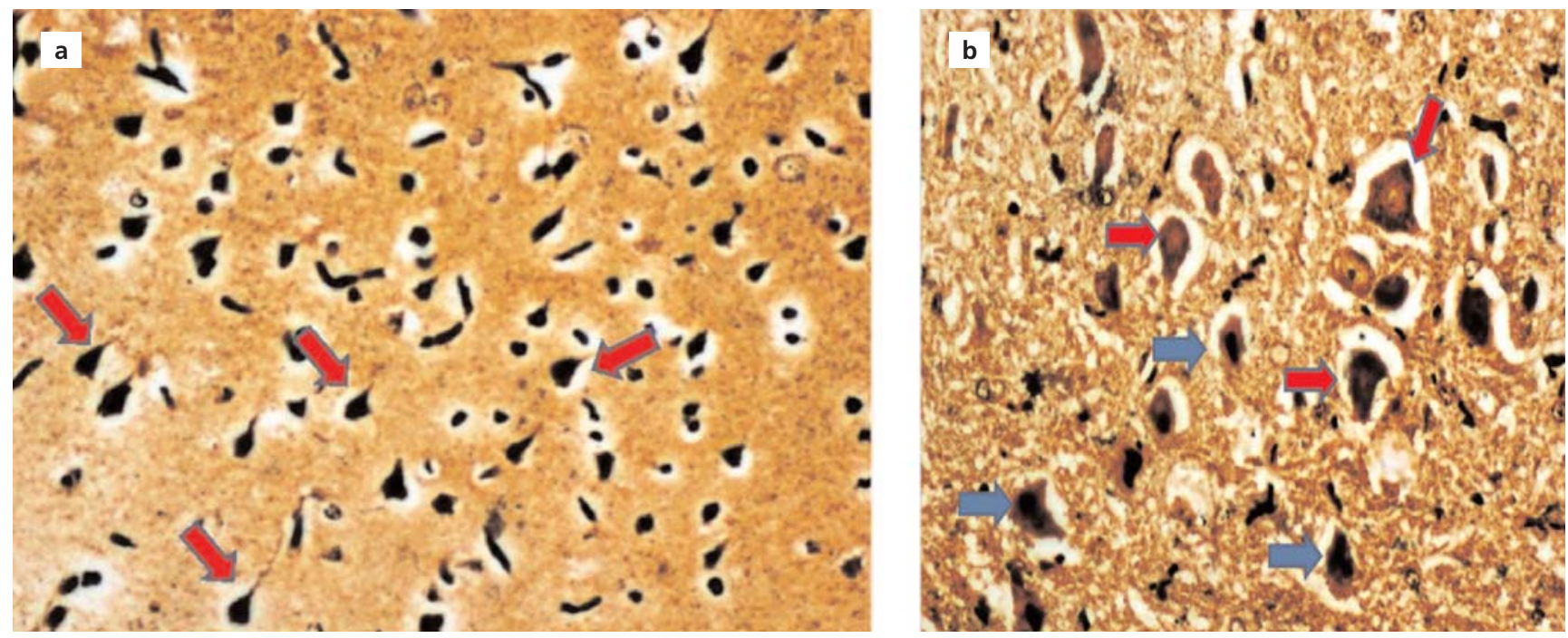

Figure 2. (a) The control group appeared normal with intact neurons (red arrows). (b) Group with administration of water contaminated with lead showed features of neurodegeneration in the cortex characterized by the presence of degenerate neurons with no nuclei (red arrows) and some with pyknotic nuclei (blue arrows) (×400 magnification, Bielschowsky's silver impregnation staining). [Color figure can be viewed in the online issue, which is available at www.anatomy.org.tr]

The neuronal membrane and presence of neurodegenerative features in the prefrontal cortex of the experimental animals throughout the 65 days of exposure are demonstrated using Bielschowsky's silver staining method as seen in Figure 2. Sections from the control group revealed normal neurons with a well-outlined neuronal membrane (Figure 2a). The treatment group showed neurons with different degenerative features (Figure 2b). The distinct morphological features observed in the treatment group also define apoptotic neuronal cell death in pathological condition. ${ }^{[50]}$
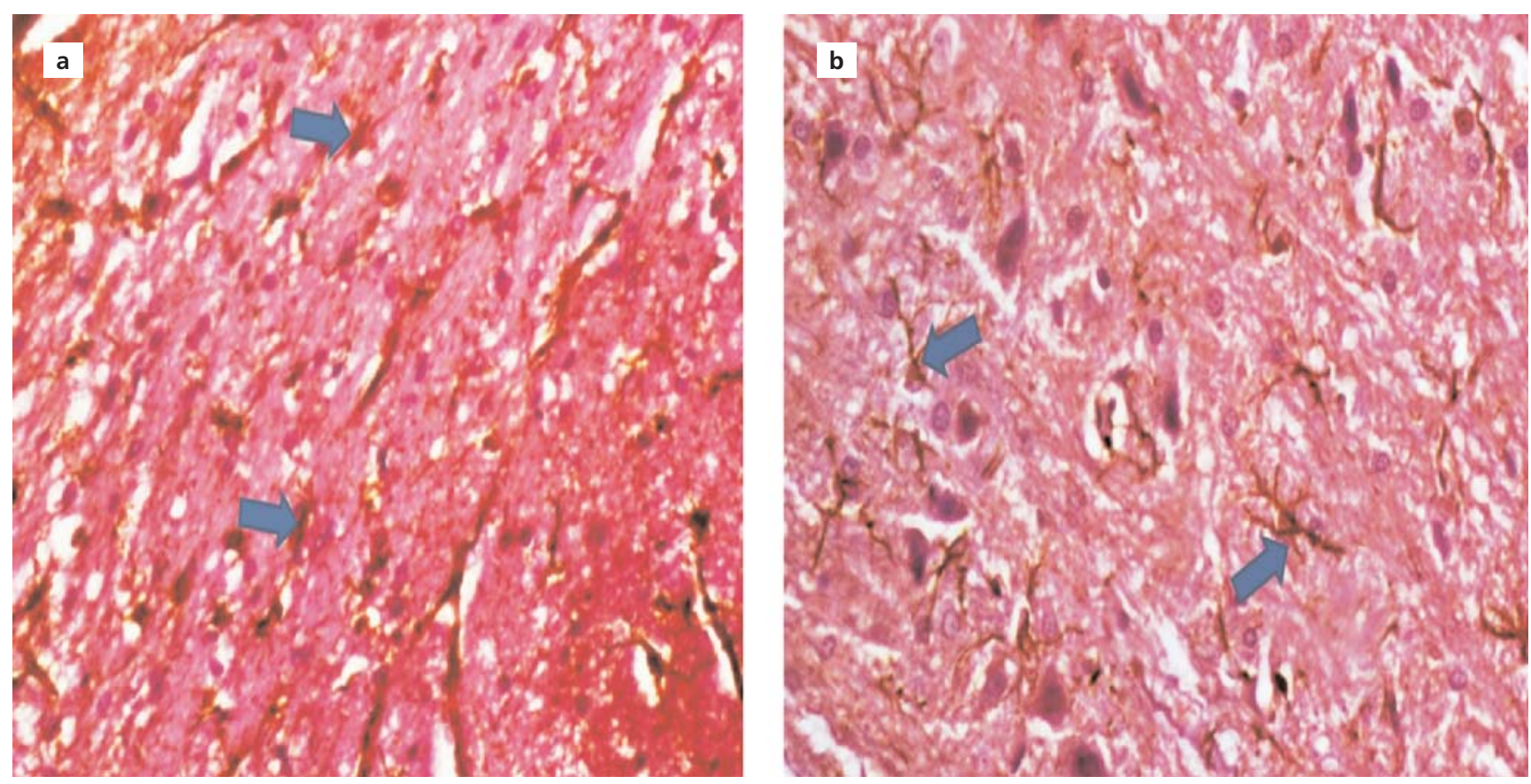

Figure 3. (a) Control group showed mild astrocytic immunoreactivity with specific and uniform staining for glial fibrillary acidic protein (GFAP) (blue arrows). (b) Group with water contaminated with lead administration depicted strong GFAP immunoreactivity with numerous intensely stained astrocytes (blue arrows) ( $\times 400$ magnification, GFAP immunostaining). [Color figure can be viewed in the online issue, which is available at www.anatomy.org.tr] 
Immunohistochemical expression of glial fibrillary acidic protein (GFAP) (Figure 3) immunostaining revealed GFAP-immunoreactive astroglia-like cells were increased in proportion, forming gliosis in the treatment group when compared with the control. GFAP uniquely marks for astrocytes which provide structural support and strength to the surrounding neurons in the central nervous system. ${ }^{[51,52]}$ The immunoreactivity of GFAP increased during reactive gliosis characterized by astrocyte hyperplasia and hypertrophy as observed in Figure $\mathbf{3} \mathbf{b}^{[52]}$ Microglial and astrocytes are effectors of neuroinflammation. $^{[32]}$ Neuroinflammation involving astrogliosis and microglial activation is common to several neurodegenerative disorders. ${ }^{[53]}$ The long-term impact of neuroinflammation-induced cell death is engendered by increased production of reactive oxygen and nitrogen species (RONS). ${ }^{[5-56]}$ Excessive generation of RONS during oxidative stress is the major mechanism for the pathological effect of heavy metals, lead inclusive.$^{[32,57-59]}$ RONS are principally involved in arousing apoptotic cell death by nitrosative or irreversible oxidative damage to neuronal elements. ${ }^{[5,56]}$

The demonstration of oxidative stress was also shown by immunohistochemical expression of induced nitric oxide synthase (iNOS) (Figure 4). iNOS immunoreactivity revealed increased immunointensity in treatment groups (Figure $4 b$ ) when compared with control groups
(Figure 4a). Nitric oxide (NO) is mainly synthesized by nitric oxide synthase (NOS) through the conversion of Larginine to $\mathrm{NO}$ and L-citrulline in mammals. ${ }^{[60]} \mathrm{NO}$ plays a vital role in both physiological and pathological processes in humans. Excessive production of $\mathrm{NO}$ as invoked by neuroinflammation is implicated as one major causative agent for several neurodegenerative disorders pathogenesis. ${ }^{[56]}$ Neuronal NO synthase is documented to be the main NOS isoform in the brain. ${ }^{[61,62]} \mathrm{On}$ the contrary, iNOS is not normally expressed or comes with minimal expression in the brain. ${ }^{[63,64]}$ Nevertheless, increased iNOS expression in neuroglia and invading macrophages in response to brain injuries is revealed in pathological conditions. ${ }^{[65,66]}$ Acute injury and iNOS upregulation may result in cell death. ${ }^{[6,68]}$ All the same, chronic neurodegenerative disorders will ensue when a large amount of NO is produced over a prolonged period of time. ${ }^{[69]}$

\section{Conclusion}

The findings of this study show that lead, obtained from the three geographical zones of Kwara Nigeria, may have a possible pathogenic role in development of neurodegenerative disorders and emphasize the effects of exposure to this environmental pollutant.
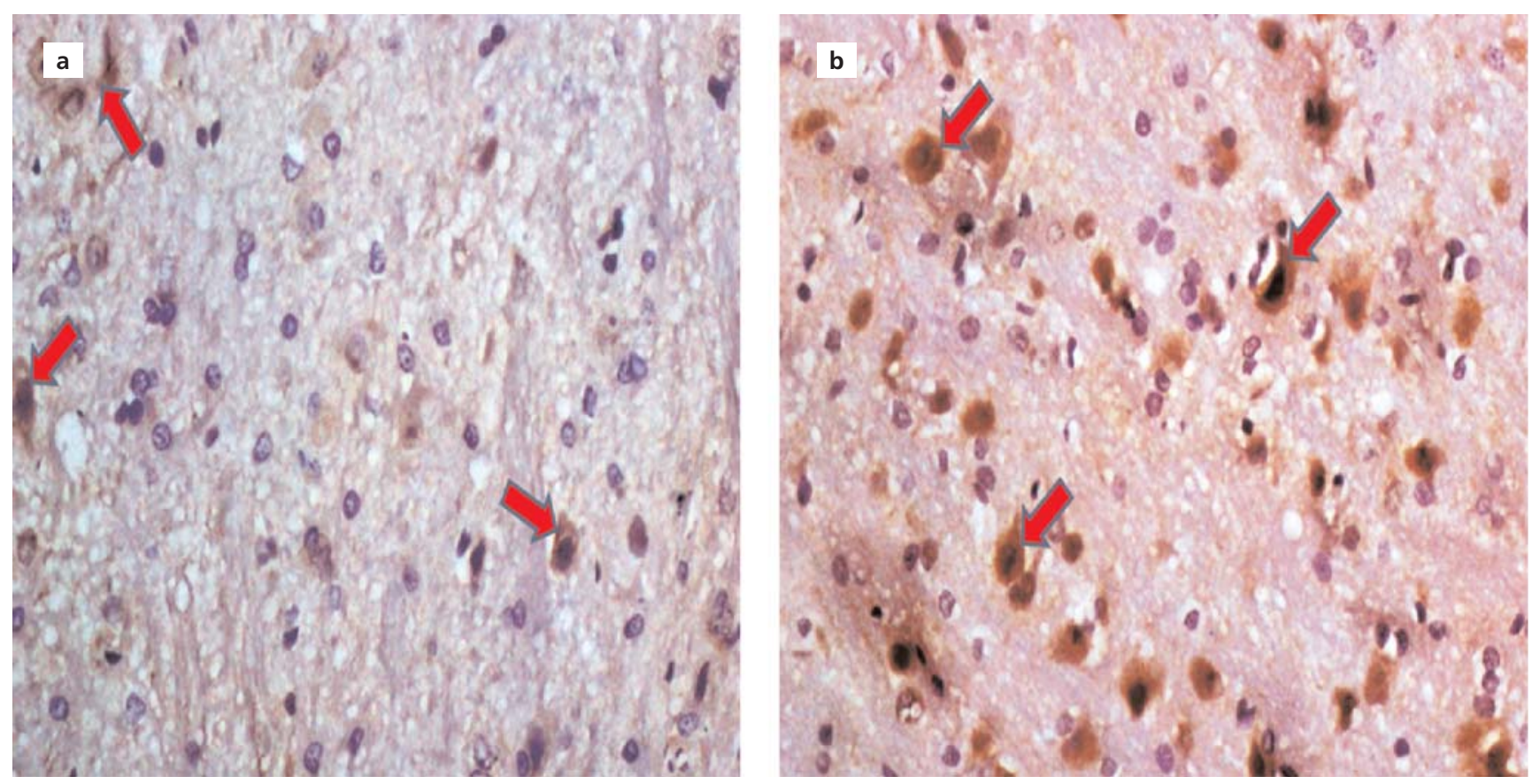

Figure 4. (a) Control group showed mild NOS immunostaining (red arrows). (b) Group administered with lead contaminated water revealed strong iNOS immunoreactivity ( $\times 400$ magnification, iNOS immunostaining). [Color figure can be viewed in the online issue, which is available at www.anatomy.org.tr] 


\section{Acknowledgements}

The authors acknowledge Mr. Adekunle Fowotade the technical head of Pathology Department, University of Ilorin Teaching Hospital (UITH) for granting access to use their laboratory for this work and other staff especially Pastor Oluwumi Olutunde and Mrs. Akanbiola for their technical input.

\section{References}

1. World Health Organization. World report on disability 2011 [Internet]. [Retrieved: August 11, 2016] Available from: http://www. who.int/disabilities/world_report/2011/en/index.html.

2. Maulik PK, Mascarrnhas MN, Mathers CD, Dua T, Saxena S. Prevalence of intellectual disability: a meta-analysis of populationbased studies. Res Dev Disabil 2011;32:419-36.

3. Neal AP, Guilarte TR. Mechanisms of heavy metal neurotoxicity. Toxicol Res 2013;2:99-114.

4. Islam MS, Ahmed MK, Habibullah-Al-Mamun M, Hoque MF. Preliminary assessment of heavy metal contamination in surface sediments from a river in Bangladesh. Environmental Earth Sciences 2015;73:1837-48.

5. Adeniyi TD, Achukwu PU, Abubakar AA. Frequency of electronics waste generated heavy metals in urban waterways. International Journal of Human Capital in Urban Management 2017;2:89-100.

6. Onwughara NI, Umeobika UC, Obianuko PN, Iloamaeke MI. Emphasis on effects of storm runoff in mobilizing the heavy metals from leachate on waste deposit to contaminate Nigerian waters: improved water quality standards. International Journal of Environmental Science and Development 2011;2:55-63.

7. Grant K, Goldizen FC, Sly PD, Brune M, Neira M, van den Berg M, Norman RE. Health consequences of exposure to e-waste: a systematic review. Lancet Glob Health 2013;1:e350-61.

8. Huang J, Nkrumah PN, Anim DO, Mensah E. E-Waste disposal effects on the aquatic environment: Accra, Ghana. Rev Environ Contam Toxicol 2014;229:19-34.

9. Adesina OS. The negative impact of globalization on Nigeria. International Journal of Humanities and Social Science 2012;2:193201.

10. Osibanjo O, Nnorom IC. The challenge of electronic waste (ewaste) management in developing countries. Waste Manag Res 2007;25:489-501.

11. Afiukwa JN, Agunwamba JC, Eneh OC. Reducing environmental pollution: acid-precipitation of lead from electrical and electronic equipment. Journal of Chemical Society of Nigeria 2015;40:143-6.

12. Onwughara IN, Nnorom IC, Kanno OC. Issues of roadside disposal habit of municipal solid waste, environmental impacts and implementation of sound management practices in developing country: Nigeria. International Journal of Environmental Science and Development 2010a;1:409-17.

13. Onwughara NI, Nnorom IC, Kanno OC, Chukwuma RC. Disposal methods and heavy metals released from certain electrical and electronic equipment wastes in Nigeria: adoption of environmental sound recycling system. International Journal of Environmental Science and Development 2010b;1:290-6.

14. Azuka AI. The influx of used electronics into Africa: a perilous trend. Law Environment and Development Journal 2009;5:90.

15. Robinson BH. E-waste: an assessment of global production and environmental impacts. Sci Total Environ 2009;408:183-91.

16. Schmidt CW. Unfair trade: e-waste in Africa. Environ Health Perspect 2006;114:232-5.
17. Ogungbuyi O, Nnorom IC, Osibanjo O, Schluep M. E-waste country assessment Nigeria. Report of UNEP E-waste Africa project for Nigeria. Ibadan, Nigeria: Basel Convention Coordinating Centre in Nigeria (BCCC-Nigeria); 2012. 230 p.

18. Ousman WZ. Environmental impact assessment of waste electronic and electrical equipment (WEEE) management practices in developing countries through leaching test. African Journal of Environmental Science and Technology 2015;9:671-81.

19. Sepúlveda A, Schluep M, Renaud FG, Streicher M, Kuehr R, Hagelüken C, Gerecke AC. A review of the environmental fate and effects of hazardous substances released from electrical and electronic equipments during recycling: Examples from China and India. Environmental Impact Assessment Review 2010;30:28-41.

20. Li Y, Richardson JB, Bricka RM, Niu X, Yang H, Li L, Jimenez A. Leaching of heavy metals from e-waste in stimulated landfill columns. Waste Manag 2009;29:2147-50.

21. Galadima A, Garba ZN, Leke L, Almustapha MN, Adam IK. Domestic water pollution among local communities in Nigeria causes and consequences. European Journal of Scientific Research 2011;52:592-603.

22. Izah SC, Chakrabarty N, Srivastav AL. A review on heavy metal concentration in potable water sources in Nigeria: human health effects and mitigating measures. Exposure and Health 2016;8:285-304.

23. Mason LH, Harp JP, Yan DY. Pb neurotoxicity: neuropsychological effects of lead toxicity. Biomed Res Int 2014;840547.

24. Davis JR, Allen P, Lampman S, Zorc TB, Henry SD, Daquila JL, Ronke AW. Metals handbook: properties and selection: nonferrous alloys and special-purpose materials. Novelty $(\mathrm{OH})$ : ASM International; 1990. 3470 p.

25. Eneh OC, Agunwamba JC. E-waste management in Africa: recycling of crude lead-extract from e-waste items. Journal of Applied Sciences 2011;11:3215-20.

26. Chen A, Dietrich KN, Huo X, Ho S. Developmental neurotoxicant in E-Waste: an emerging health concern. Environ Health Perspect 2011;119:43-438.

27. Fishbein B. Waste in the wireless world: the challenge of cell phones. New York (NY): Inform; 2002. 106 p.

28. Ibrahim U. E-waste environmental pollution and health risk implications for early child care, growth and development in Nigeria. Sustainable Human Development Review 2017;9:41-54.

29. Song Q, Li J. A systematic review of the human body burden of ewaste exposure in China. Environ Int 2014;68:82-93.

30. Fakayode SO, Olu-Owolabi BI. Heavy metal contamination of roadside topsoil in Osogbo, Nigeria: its relationship to traffic density and proximity to highways. Environmental Geology 2003;44:150-7.

31. Lincoln JD, Ogunseitan OA, Saphores JD, Shapiro AA. Leaching assessments of hazardous materials in cellular telephones. Environ Sci Technol 2007;41:2572-8.

32. Monnet-Tschudi F, Zurich MG, Boschat C, Corbaz A, Honegger P. Involvement of environmental mercury and lead in the etiology of neurodegenerative diseases. Rev Environ Health 2006;21:105-17.

33. Bellinger DC. Very low lead exposures and children's neurodevelopment. Curr Opin Pediatr 2008;20:172-7.

34. Dorsey CD, Lee BK, Bolla KI, Weaver VM, Lee SS, Lee GS, Todd AC, Shi W, Schwartz BS. Comparison of patella lead with blood lead and tibia lead and their associations with neurobehavioral test scores. J Occup Environ Med 2006;48:489-96.

35. Lidsky TI, Schneider JS. Lead neurotoxicity in children: basic mechanisms and clinical correlates. Brain 2003;126:5-19.

36. Daniel AT, Adekilekun TA, Adewale MA, Adekemi AT. Cyanideinduced hyperthyroidism in male Wistar rats. Niger Med J 2014;55: 246-9. 
37. Adeyemi O, Oloyede OB, Oladiji AT. Physicochemical and microbial characteristics of leachate-contaminated groundwater. Asian Journal of Biochemistry 2007;2:343-8.

38. Van Zutphen LFM, Baumans V, Beynen AC. Principles of laboratory animal science. Amsterdam: Elsevier. 1993. p. 265-276.

39. Drury RA, Wellington EA. Carleton Histological Technique. 5th ed. New York (NY): Oxford University Press; 1980. 190 p.

40. Bancroft JD, Gamble H. Theory and practice of histological technique, 6th ed. Philadelphia: Churchill Livingstone Elsevier, New York; 2008. 240 p.

41. Marsland TA, Glees P, Erikson LB. Modification of Glee's silver impregnation for paraffin sections. J Neuropathol Exp Neurol 1954; 13:587-91.

42. Lyck L, Dalmau I, Chemnitz J, Finsen B, Schroder HD. Immunohistochemical markers for quantitative studies of neurons and glia in human neocortex. J Histochem Cytochem 2008;56:201-21.

43. Delcambre GH, Liu J, Herrington JM, Vallario K, Long MT. Immunohistochemistry for the detection of neural and inflammatory cells in equine brain tissue. PeerJ 2016;4:e1601.

44. Hoehn T, Felderhoff-Mueser U, Maschewski K, Stadelmann C, Sifringer M, Bittigau P, Koehne P, Hoppenz M, Obladen M, Bührer C. Hyperoxia causes inducible nitric oxide synthase-mediated cellular damage to the immature rat brain. Pediatr Res 2003;54:179-84.

45. Semendeferi K, Armstrong E, Schleicher A, Zilles K, Van Hoesen GW. Prefrontal cortex in humans and apes: a comparative study of area 10. Am J Phys Anthropol 2001;114:224-41.

46. Sharifi AM, Baniasadi S, Jorjani M, Rahimi F, Bakhshayesh M. Investigation of acute lead poisoning on apoptosis in rat hippocampus in vivo. Neurosci Lett 2002;329:45-8.

47. Osten P, Margrie TW. Mapping brain circuitry with a light microscope. Nat Methods 2013;10:515-23.

48. Olajide OJ, Akinola OB, Ajao MS, Enaibe BU. Sodium azide-induced degenerative changes in the dorsolateral prefrontal cortex of rats: attenuating mechanisms of kolaviron. Eur J Anat 2016;20:47-64.

49. Stefanis L, Burke RE, Greene LA. Apoptosis in neurodegenerative disorders. Curr Opin Neurol 1997;10:299-305.

50. Wyllie AH, Kerr JF, Currie AR. Cell death: the significance of apoptosis. Int Rev Cytol 1980;68:251-306.

51. Mccall MA, Gregg RG, Behringer RR, Brenner M, Delaney CL, Galbreath EJ, Zhang CL, Pearce RA, Chiu SY, Messing A. Targeted deletion in astrocyte intermediate filament (Gfap) alters neuronal physiology. Proc Natl Acad Sci U S A 1996;93:6361-6.

52. Eng L, Ghirnikar R, Lee Y. Glial fibrillary acidic protein: GFAPthirty-one years (1969-2000). Neurochem Res 2000;25:1439-51.

53. Blasko I, Stampfer-Koutchev M, Robastscher P, Veerhuis R, Eikelenboom P, Grubeck-Loebenstein B. How chronic inflammation can affect the brain and support the development of Alzheimer's disease in old age: the role of microglia and astrocyte. Aging Cell 2004;3:169-76.

54. Hsiang J, Díaz E. Lead and developmental neurotoxicity of the central nervous system. Current Neurobiology 2011;2:35-42.

55. Nakagawa T, Yokozawa T. Direct scavenging of nitric oxide and superoxide by green tea. Food Chem Toxicol 2002;40:1745-50.

56. Yuste JE, Tarragon E, Campuzano CM, Ros-Bernal F. Implications of glial nitric oxide in neurodegenerative diseases. Front Cell Neurosci 2015;9:322.

57. Antonio-García MT, Massó-Gonzalez EL. Toxic effects of perinatal lead exposure on the brain of rats: involvement of oxidative stress and the beneficial role of antioxidants. Food Chem Toxicol 2008;46:2089_ 95.

58. Khan D, Qayyum S, Saleem S, Khan F. Lead-induced oxidative stress adversely affects health of the occupational workers. Toxicol Ind Health 2008;24:611-8.

59. Tsang F, Soong TW. Interactions between environmental and genetic factors in the pathophysiology of Parkinson's disease. IUBMB Life 2003;55:323-7.

60. Knowles RG, Moncada S. Nitric oxide synthases in mammals. Biochem J 1994;298:249-58.

61. Huang PL, Dawson TM, Bredt DS, Snyder SH, Fishman MC. Targeted disruption of the neuronal nitric oxide synthase gene. Cell 1993;75:1273-85.

62. Dawson TM, Dawson VL. Nitric oxide synthase: role as a transmitter/mediator in the brain and endocrine system. Annu Rev Med 1996;47:219-27.

63. Lowenstein CJ, Glatt CS, Bredt DS, Snyder SH. Cloned and expressed macrophage nitric oxide synthase contrasts with the brain enzyme. Proc Natl Acad Sci U S A 1992;89:6711-5.

64. Keilhoff G, Seidel B, Noack H, Tischmeyer W, Stanek D, Wolf G. Patterns of nitric oxide synthase at the messenger RNA and protein levels during early rat brain development. Neurosci 1996;75:1193201.

65. Simmons ML, Murphy S. Induction of nitric oxide synthase in glial cells. J Neurochem 1992;59:897-905.

66. Wallace MN, Fredens K. Activated astrocytes of the mouse hippocampus contain high levels of NADPH-diaphorase. Neuroreport 1992;3:953-6.

67. Adamson DC, Wildemann B, Sasaki M, Glass JD, McArthur JC, Christov VI, Ted M, Dawson TM, Dawson VL. Immunologic NO synthase: elevation in severe AIDS dementia and induction by HIV1 gp41. Science 1996;274:1917-21.

68. Iadecola C, Xu X, Zhang F, el-Fakahany EE, Ross ME. Marked induction of calcium-independent nitric oxide synthase activity after focal cerebral ischemia. J Cereb Blood Flow Metab 1995;15:52-9.

69. Nathan C, Xie QW. Regulation of biosynthesis of nitric oxide. J Biol Chem 1994;269:13725-8.

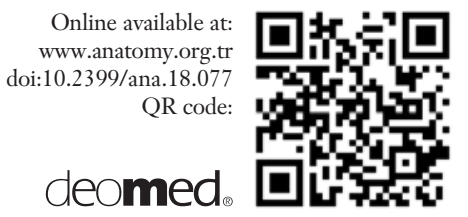

Correspondence to: Temidayo Daniel Adeniyi, PhD

Department of Medical Laboratory Science, School of Basic Medical Sciences, College of Pure and Applied Sciences, Kwara State University, Malete, Kwara State, Nigeria Phone: +2348030612404

e-mail: temidayo.adeniyi@kwasu.edu.ng

Conflict of interest statement: No conflicts declared.

This is an open access article distributed under the terms of the Creative Commons Attribution-NonCommercial-NoDerivs 3.0 Unported (CC BY-NCND3.0) Licence (http://creativecommons.org/licenses/by-nc-nd/3.0/) which permits unrestricted noncommercial use, distribution, and reproduction in any medium, provided the original work is properly cited. Please cite this article as: Adeniyi DT, Achukwu PU. Lead contamination induces neurodegeneration in prefrontal cortex of Wistar rats. Anatomy 2018;12(3):128-134. 